\title{
PENGARUH PENAMBAHAN Pediococcus acidilactici F-11 SEBAGAI KULTUR STARTER TERHADAP KUALITAS RUSIP TERI (Stolephorus sp.)
}

\author{
Arifah Kusmarwati"), Endang Sri Heruwati"), Tyas Utami*"), dan Endang Sutriswati Rahayu")
}

\section{ABSTRAK}

Penelitian ini bertujuan untuk mengevaluasi pengaruh penambahan Pediococcus acidilactici F-11 sebagai kultur starter terhadap kualitas rusip melalui proses fermentasi. Rusip teri dibuat melalui fermentasi tanpa dan dengan penambahan starter dengan variasi penggaraman 10, 15 , dan $20 \%$ dan masing-masing ditambah gula merah $10 \%$ dari berat ikan pada suhu kamar $(30 \pm$ $2^{\circ} \mathrm{C}$ ) selama 12 hari. Parameter yang diamati meliputi parameter mikrobiologi (ALT, total bakteri asam laktat (BAL), dan total coliform), kimiawi ( $\mathrm{pH}$, total asam, TVB, kadar air, dan kadar garam), dan sensori. Hasil penelitian menunjukkan bahwa penambahan Pediococcus acidilactici F-11 dapat meningkatkan total BAL dan menurunkan total coliform produk rusip yang dihasilkan. Selain itu dapat mempersingkat waktu fermentasi dari 12 hari menjadi 9 hari dan menghasilkan produk rusip dengan sifat sensori yang lebih disukai terutama pada perlakuan penggaraman $15 \%$. Produk rusip yang dihasilkan memiliki total BAL lebih tinggi yaitu sebesar 7,47 log, total coliform lebih rendah yaitu 3,34 log daripada rusip tanpa starter serta memiliki rasa dan tekstur yang lebih disukai.

\section{ABSTRACT: Effect of the addition of Pediococcus acidilactici F-11 as a starter culture on the quality of rusip. By: Arifah Kusmarwati, Endang Sri Heruwati, Tyas Utami and Endang Sutriswati Rahayu}

Research was conducted to evaluate the effect of addition of Pediococcus acidilactici F-11 as starter culture on the quality of rusip through fermentation process. Rusip was processed by fermentation either with or without Pediococcus acidilactici F-11 with the addition of 10, 15 and $20 \%(w / w)$ salt and $10 \%(w / w)$ brown sugar which was done at room temperature for 12 days. Observations were conducted including microbiological analysis (total plate count, total lactic acid bacteria ( $L A B)$ and total coliform), chemical analysis ( $\mathrm{pH}$, total acid, TVB, moisture content, salt content), and sensory. The result showed that Pediococcus acidilactici F-11 addition could increase total $L A B$ count and decrease total coliform of rusip. Beside that it shortened fermentation time from 12 days to 9 days and produced more acceptable rusip, especially on the $15 \%$ salt treatment. The rusip had higher total LAB count, i. e $7.47 \mathrm{log}$ and lower total coliform, i. e 3.34 log than that of without starter and also had the more acceptable taste and texture.

KEYWORDS: $\quad$ rusip, fermentation, Pediococcus acidilactici F-11

\section{PENDAHULUAN}

Produk fermentasi ikan seperti bekasam, peda, wadi, kecap ikan, dan terasi ikan/udang telah banyak dikenal di Indonesia. Rusip merupakan salah satu produk fermentasi ikan yang khas dari Propinsi Kepulauan Bangka Belitung. Di tempat asalnya rusip dibuat dari ikan teri/bilis segar yang diolah ketika ikan melimpah. Dalam kondisi tersebut, nelayan setempat melakukan upaya pengawetan berupa penggaraman yang dilanjutkan dengan pemeraman ikan pada suhu ruang. Pemeraman dilakukan selama 7 hari hingga 2 minggu secara anaerob. Pemberian garam di awal proses fermentasi bervariasi antara 10-25\%, selanjutnya ditambahkan gula aren sekitar $10 \%$ dengan atau tanpa penambahan beras (Yuliana, 2007).

Pengolahan produk rusip secara tradisional memiliki beberapa kelemahan terutama dalam hal mutu produk yang relatif rendah. Madani et al., 2007 melaporkan bahwa produk rusip mengandung TVB mencapai $2348 \mathrm{mgN} / 100 \mathrm{~g}$. Batas maksimum TVB untuk ikan olahan dengan penggaraman sebesar 200 $\mathrm{mgN} / 100 \mathrm{~g}$ (Connel, 1980). Rendahnya kualitas olahan ikan termasuk rusip dapat terjadi karena pada umumnya proses fermentasi ikan secara tradisional berlangsung secara spontan sehingga bakteri pembusuk tumbuh lebih cepat mendahului pertumbuhan bakteri asam laktat yang diketahui

\footnotetext{
") Peneliti pada Balai Besar Riset Pengolahan Produk dan Bioteknologi Kelautan dan Perikanan, Balitbang KP, KKP; JI. KS. Tubun Petamburan VI, Slipi, Jakarta Pusat; E-mail: iin_amri@yahoo.com

*) Dosen pada Fakultas Teknologi Pertanian, Universitas Gadjah Mada; JL. Susio Yustisia, Bulaksumur, Yogyakarta
} 
mampu menghambat pertumbuhan bakteri pembusuk (Ustadi et al., 2002). Selain itu produk dipasarkan dalam kondisi terendam larutan garam yang memungkinkan proses fermentasi terus berjalan. Kondisi ini memungkinkan produk mudah mengalami kemunduran mutu. Produk rusip di pasaran juga mengandung garam dengan kadar yang rendah sehingga lebih mudah busuk, atau sebaliknya mengandung garam dengan kadar yang tinggi, sehingga beresiko untuk terjadinya gejala tekanan darah tinggi bagi yang mengkonsumsinya.

Peranan bakteri asam laktat pada produk fermentasi ikan telah banyak dilaporkan antara lain oleh Morzel et al. (1997); Rahayu (1997); Tanasupawat \& Komagata (1999); Muller et al. (2002); Ustadi et al. (2004); Rinto (2006); Nurulita et al. (2007); Riebroy et al. (2008). Bakteri asam laktat dari rusip telah berhasil diisolasi dan diidentifikasi sebagai Lactobacillus, Streptococcus, Leuconostoc, Pediococcus, dan Enterococcus. BAL asal rusip tersebut mampu menghasilkan bakteriosin (Dessi, 1999 dalam Yuliana 2007 dan Sakti, 2009). Bakteriosin ini merupakan peptida atau senyawa protein yang memiliki aktivitas antimikrobia (Kusmiati \& Malik, 2002; Galvez et al., 2007).

Pediococcus acidilactici F-11 merupakan salah satu BAL yang telah digunakan pada fermentasi ikan peda dan ina sua (ikan asin) gurami (Nendissa, 2001; Rinto, 2006). Bakteri ini dilaporkan mampu menghasilkan bakteriosin yang mampu menghambat berbagai jenis bakteri pembusuk dan patogen serta mampu meningkatkan kualitas produk. Penggunaan starter tersebut diharapkan dapat menghasilkan produk yang lebih konsisten dalam hal mutu dan karakteristik produk (Nendissa, 2001; Rinto, 2006).

Penelitian ini bertujuan untuk mempelajari pengaruh penambahan Pediococcus acidilactici F11 sebagai kultur starter pada proses fermentasi rusip dalam memperbaiki kualitas mikrobiologis, kimiawi, dan sifat sensori produk.

\section{BAHAN DAN METODE}

Bahan-bahan untuk pembuatan rusip di laboratorium terdiri dari ikan teri (Stolephorus sp.), bakteri asam laktat Pediococcus acidilactici F-11, sukrosa (gula aren), dan garam. Ikan teri segar diperoleh dari pengumpul di Pusat Pelelangan Ikan Labuhan Banten, bakteri asam laktat Pediococcus acidilactici F-11 diperoleh dari Food and Nutrition Culture Collection Pusat Studi Pangan dan Gizi Universitas Gadjah Mada, Yogyakarta. Sedangkan sukrosa (gula aren) dan garam dibeli dari pasar Beringharjo Yogyakarta.
Media yang digunakan yaitu TGE broth (Tryptone Glucose Yeast Extract), MRS (DeMan, Rogosa and Sharpe), PCA (Plate Count Agar) dan VRBA (Violet Red Bile Salt Agar). Media TGE broth digunakan untuk menumbuhkan starter, media MRS (Oxoid) agar yang ditambah $\mathrm{CaCO}_{3}, 1 \%$ dan natrium azida $0,2 \%$ digunakan sebagai media enumerasi/perhitungan jumlah bakteri asam laktat, media PCA (Oxoid) digunakan untuk enumerasi total bakteri.

Penanganan awal teri segar yang diperoleh dari Labuhan Banten adalah teri segar langsung dimasukkan ke dalam coolbox yang telah diisi es curah lalu dibawa ke laboratorium Balai Besar Riset Pengolahan Produk dan Bioteknologi Kelautan dan Perikanan (BBRP2BKP), Jakarta. Terhadap ikan teri segar kemudian dilakukan analisis kesegaran, yaitu analisis kimia (TVB) dan mikrobiologi (Angka Lempeng Total/ALT).

Pembuatan rusip dilakukan melalui proses fermentasi tanpa starter dan dengan starter pada suhu kamar $\left(30 \pm 2^{\circ} \mathrm{C}\right)$ selama 12 hari. Fermentasi menggunakan starter diawali dengan pembuatan kultur starter $P$. acidilactici F-11. Pembuatan kultur starter $P$. acidilactici $\mathrm{F}-11$ sebanyak $100 \mathrm{~mL}$ dilakukan dengan cara berikut : 1 ose kultur cair $P$. acidilactici F-11 dimasukkan ke dalam $5 \mathrm{~mL}$ media TGE cair dan diinkubasi pada suhu $35^{\circ} \mathrm{C}$ selama 24 jam. Selanjutnya sebanyak $1 \mathrm{~mL}$ kultur dipindahkan ke dalam $4 \mathrm{~mL}$ media TGE cair. Setelah diinkubasi selama 24 jam, $5 \mathrm{~mL}$ kultur dipindahkan kembali ke dalam $95 \mathrm{~mL}$ media TGE cair dan kembali diinkubasi selama 24 jam. Seratus mililiter kultur BAL yang berisi $10^{7} \mathrm{cfu} / \mathrm{mL}$ siap digunakan sebagai starter.

Adapun prosedur pembuatan rusip adalah sebagai berikut: ikan teri (Stolephorus sp.) dicuci bersih, ditiriskan dan ditimbang lalu dilumuri garam 10, 15 , dan $20 \%$ dan gula aren $10 \%$ dari berat ikan. Selanjutnya ikan ditambah air steril (sebagai kontrol/ tanpa starter) atau kultur starter P. acidilactici F-11; setiap $5 \mathrm{~mL}$ kultur starter atau $5 \mathrm{~mL}$ air steril digunakan untuk menginokulasi 100 gram ikan yang akan difermentasikan. Setelah diaduk secara merata kemudian ikan sebanyak $150 \mathrm{~g}$ dimasukkan ke dalam wadah (botol gelas) bersih volume $300 \mathrm{~mL}$, ditutup rapat dengan kain dan diikat. Selanjutnya dilakukan pemeraman pada suhu ruang $\left(30 \pm 2^{\circ} \mathrm{C}\right)$ selama 12 hari. Selengkapnya diagram alir fermentasi rusip disajikan pada Gambar 1.

Sampling dilakukan sebanyak 5 kali yaitu pada hari ke-0, 3, 6, 9, dan 12 . Terhadap produk rusip dilakukan analisis mikrobiologi, kimia, dan sensori. Analisis mikrobiologi meliputi Angka Lempeng Total (ALT), total bakteri asam laktat, dan total coliform (BSN, 2006). Analisis kimia meliputi $\mathrm{pH}$, total asam, 


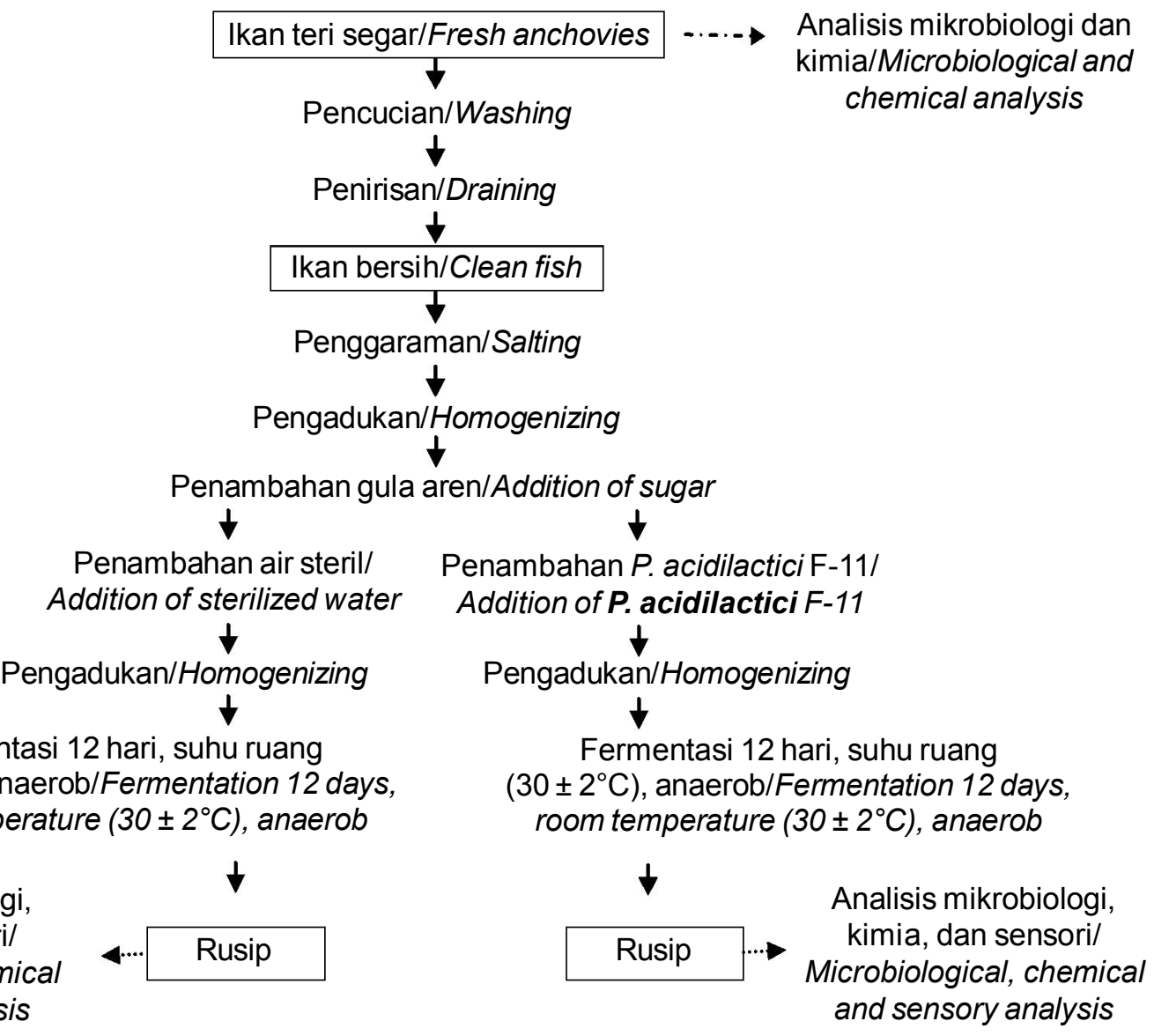

Analisis mikrobiologi, kimia, dan sensori/ Microbiological, chemical and sensory analysis

Gambar 1. Diagram alir fermentasi rusip.

Figure 1. Flow chart of rusip fermentation.

TVB, kadar air, dan kadar garam (AOAC, 1999), sedangkan analisis sensori meliputi kenampakan, bau, rasa, dan tekstur menggunakan metode skoring dengan skor 1-5 dengan skor 5 untuk mutu terbaik dan skor 1 untuk mutu terendah. Analisis sensori secara hedonik dengan skor 1-7 (skor 1: sangat tidak suka dan skor 7: sangat suka) untuk penerimaan secara umum.

Penelitian menggunakan rancangan acak lengkap faktorial dengan dua kali ulangan. Data diolah dengan

Tabel 1. Tingkat kesegaran bahan baku ikan teri

Table 1. The freshness of the raw material of anchovies

\begin{tabular}{cccc}
\hline No & Parameter/Parameter & Kandungan/Content & $\begin{array}{c}\text { Standar Maksimum/ } \\
\text { Maximum Standard }\end{array}$ \\
\hline 1 & ALT (cfu/g) & $2.11 \times 10^{4}$ & $5 \times 10^{5}$ a) \\
2 & TVB (mgN/100 g) & 23.03 & $\left.30^{\mathrm{b}}\right)$ \\
3 & Kadar air/Moisture content $(\%)$ & 82.30 & - \\
\hline
\end{tabular}

Keterangan/Note:

a) SNI untuk ikan segar/Standard for fresh fish (BSN, 2009)

b) Standar batas maksimum untuk ikan segar/Maximum standard for fresh fish (Connel, 1980) menggunakan analisis sidik ragam (ANOVA). Apabila berbeda nyata dilanjutkan dengan uji Beda Nyata Terkecil (LSD) (Steel \& Torie, 1989).

\section{HASIL DAN BAHASAN}

\section{Bahan Baku Ikan Teri Segar}

Hasil pengamatan terhadap tingkat kesegaran bahan baku ikan teri yang digunakan disajikan pada Tabel 1. 
Jumlah bakteri pada ikan teri yang digunakan sebesar $2,11 \times 10^{4} \mathrm{cfu} / \mathrm{g}$. Hal ini menunjukkan bahwa kesegaran ikan teri yang digunakan sebagai bahan baku fermentasi rusip masih memenuhi SNI untuk ikan segar yaitu maksimum sebesar $5 \times 10^{5} \mathrm{cfu} / \mathrm{g}$ atau 1 log cycle di bawah ambang batas kesegaran. Kondisi ini memperlihatkan bahwa penanganan bahan baku di tingkat nelayan maupun pengumpul sudah cukup baik. Demikian pula dengan mutu kimiawi teri segar baik nilai TVB dan kadar air yang mengindikasikan tingkat kesegaran yang cukup baik.

\section{Perubahan Mikrobiologi Ikan selama Fermentasi Rusip}

\section{Jumlah bakteri total}

Perubahan kandungan bakteri total pada rusip kontrol dan rusip yang diinokulasi dengan starter $P$. acidilactici F-11 dapat dilihat pada Gambar 2. Dari gambar tersebut terlihat bahwa baik pada fermentasi tanpa maupun dengan penambahan starter memperlihatkan pola kenaikan jumlah bakteri total yang serupa selama proses fermentasi rusip pada suhu ruang.

Pada fermentasi tanpa starter dengan waktu pengamatan setiap 3 hari sekali, jumlah bakteri total

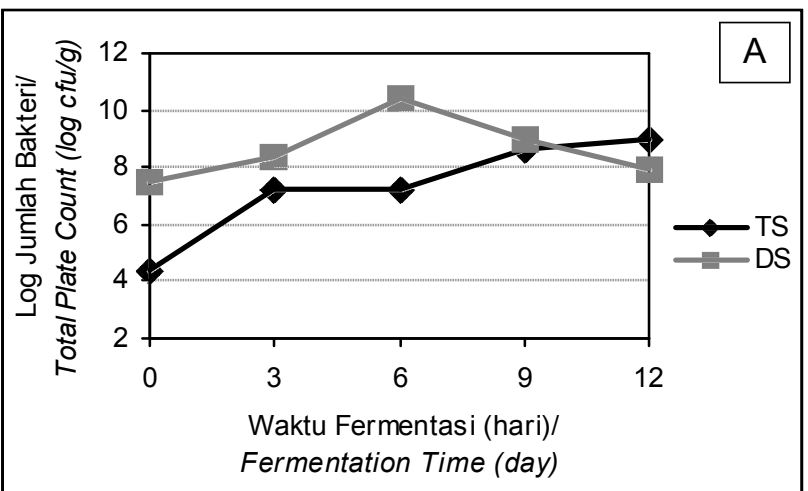

meningkat pada 3 hari ferementasi. Jumlah bakteri total mencapai puncaknya pada hari ke-9 dan 12 fermentasi (8,7 dan 8,9 log). Peningkatan tersebut menunjukkan adanya pertumbuhan bakteri halofilik/ halotoleran termasuk bakteri asam laktat selama proses fermentasi bergaram seiring meningkatnya efek penghambatan oleh garam. Gram et al. (2002) menyatakan bahwa terjadi perubahan mikroflora seiring menguatnya efek penghambatan oleh garam selama proses fermentasi. Perubahan mikroflora tersebut mengikuti pola tertentu berturut- turut dari awal hingga akhir fermentasi yaitu dari bakteri Gram negatif non fermentatif, bakteri Gram negatif fermentatif, bakteri asam laktat, yeast, dan kapang. Kemudian setelah mencapai jumlah tertinggi, nilai jumlah bakteri total mengalami penurunan. Penurunan nilai jumlah bakteri total ini terkait dengan kondisi produk yang semakin asam seiring lamanya waktu fermentasi. Bakteri asam laktat yang berperan dalam proses fermentasi mengubah glukosa dan sumber karbohidrat lain menjadi asam laktat. Selanjutnya asam yang terbentuk menurunkan $\mathrm{pH}$ produk sehingga menjadi faktor pengontrol terhadap bakteri yang tidak diinginkan selama fermentasi (Hutkins, 2006; Cocconcelli, 2007). Terkait dengan hal ini, $\mathrm{pH}$ produk rusip menurun sangat tajam dari 6,37 menjadi 4,86

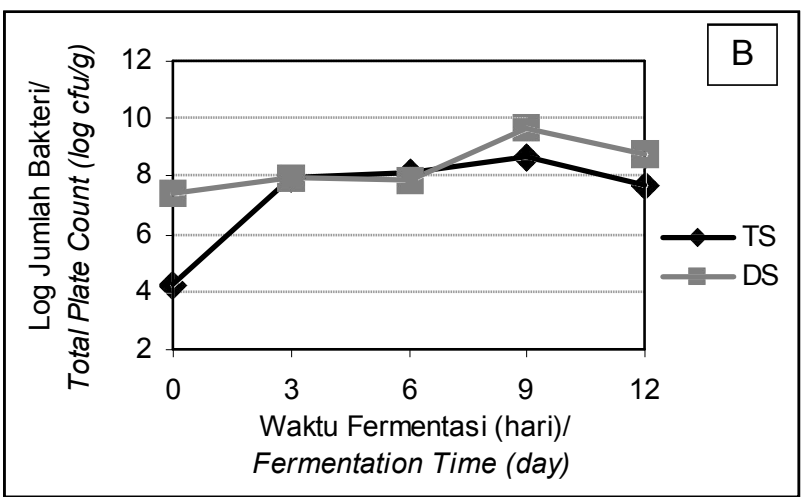

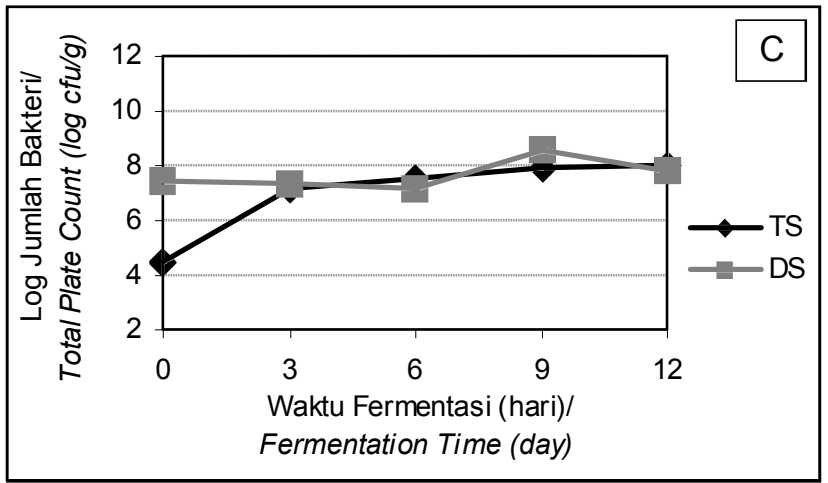

Gambar 2. Log jumlah bakteri total selama fermentasi pada A) kadar garam $10 \%$; B) kadar garam $15 \%$; dan C) kadar garam 20\% (TS: Tanpa Starter; DS: Dengan Starter)

Figure 2. Log of the total plate count during fermentation on A) $10 \%$ salt; B) $15 \%$ salt and C) $20 \%$ salt (TS: without starter; DS: with starter) 
(pada penambahan garam 10\%). Dengan penambahan garam 15 dan $20 \%, \mathrm{pH}$ produk turun berturut-turut dari 6,33 menjadi 6,09 dan dari 6,31 menjadi 6,08 selama fermentasi 12 hari (Gambar 5).

Pada fermentasi menggunakan starter, jumlah bakteri total sudah sebesar 3 log cycle lebih tinggi dari jumlah bakteri awal pada ikan, di awal proses pembuatan rusip (hari ke-0). Setelah difermentasikan selama 3 hari terjadi peningkatan jumlah bakteri total yang mencapai puncaknya pada hari ke- 6 sebesar $10,4 \log$ (penggaraman 10\%) dan pada hari ke-9 sekitar 9,5 log cfu/g (penggaraman 15 dan 20\%). Kondisi ini memperlihatkan bahwa penambahan starter mampu mempercepat proses fermentasi dari 12 hari menjadi 6 hari (penggaraman 10\%) dan dari 12 hari menjadi 9 hari (penggaraman 15 dan 20\%). Dengan demikian fermentasi rusip dengan starter hanya membutuhkan waktu 6-9 hari, sedangkan melalui fermentasi tanpa starter membutuhkan waktu fermentasi lebih lama yaitu 12 hari (Gambar 2).

Selama proses fermentasi tanpa starter, jumlah bakteri total (ALT) meningkat sejak awal fermentasi hingga hari ke-12 pada penggaraman 10 dan $20 \%$, sementara pada penggaraman $15 \%$ peningkatan ALT hanya terjadi hingga hari ke- 9 , kemudian jumlahnya menurun hingga akhir fermentasi. Pada fermentasi tanpa starter jumlah bakteri total meningkat pada penggaraman $20 \%$, berkaitan dengan kondisi $\mathrm{pH}$ lingkungan pertumbuhan bakteri, sebesar 6,02 yang masih sesuai untuk pertumbuhannya (Gambar $5 \mathrm{C}$ ). Sementara pada waktu yang sama kondisi $\mathrm{pH}$ pada penggaraman $15 \%$ adalah lebih rendah, sehingga penurunan total bakteri diduga karena pertumbuhan yang terhambat akibat kondisi yang lebih asam. Pada proses fermentasi dengan penambahan starter, jumlah bakteri total meningkat menjadi 8 dan 8,4 log setelah 3 hari masa fermentasi (penggaraman 10 dan 15\%), sebaliknya pada penggaraman $20 \%$ terjadi penurunan. Penurunan tersebut kemungkinan disebabkan oleh bakteriosin yang telah terbentuk di awal proses fermentasi. Hal ini didukung oleh nilai pH ikan 6,056,21 (Gambar 5A dan 5B) sehingga memungkinkan terserapnya pediosin (bakteriosin yang dihasilkan oleh Pediococcus) oleh bakteri. Yang \& Ray (1992) melaporkan proses terserapnya pediosin oleh bakteri secara maksimal terjadi pada $\mathrm{pH}$ 6,0-6,5. Berdasarkan Gambar 2A pada fermentasi dengan starter, bakteri total yang tumbuh pada produk rusip dengan penggaraman $10 \%$ lebih cepat menurun populasinya dibandingkan dengan rusip penggaraman 15 dan $20 \%$ (Gambar 2B dan 2C). Hal ini berkorelasi dengan pH
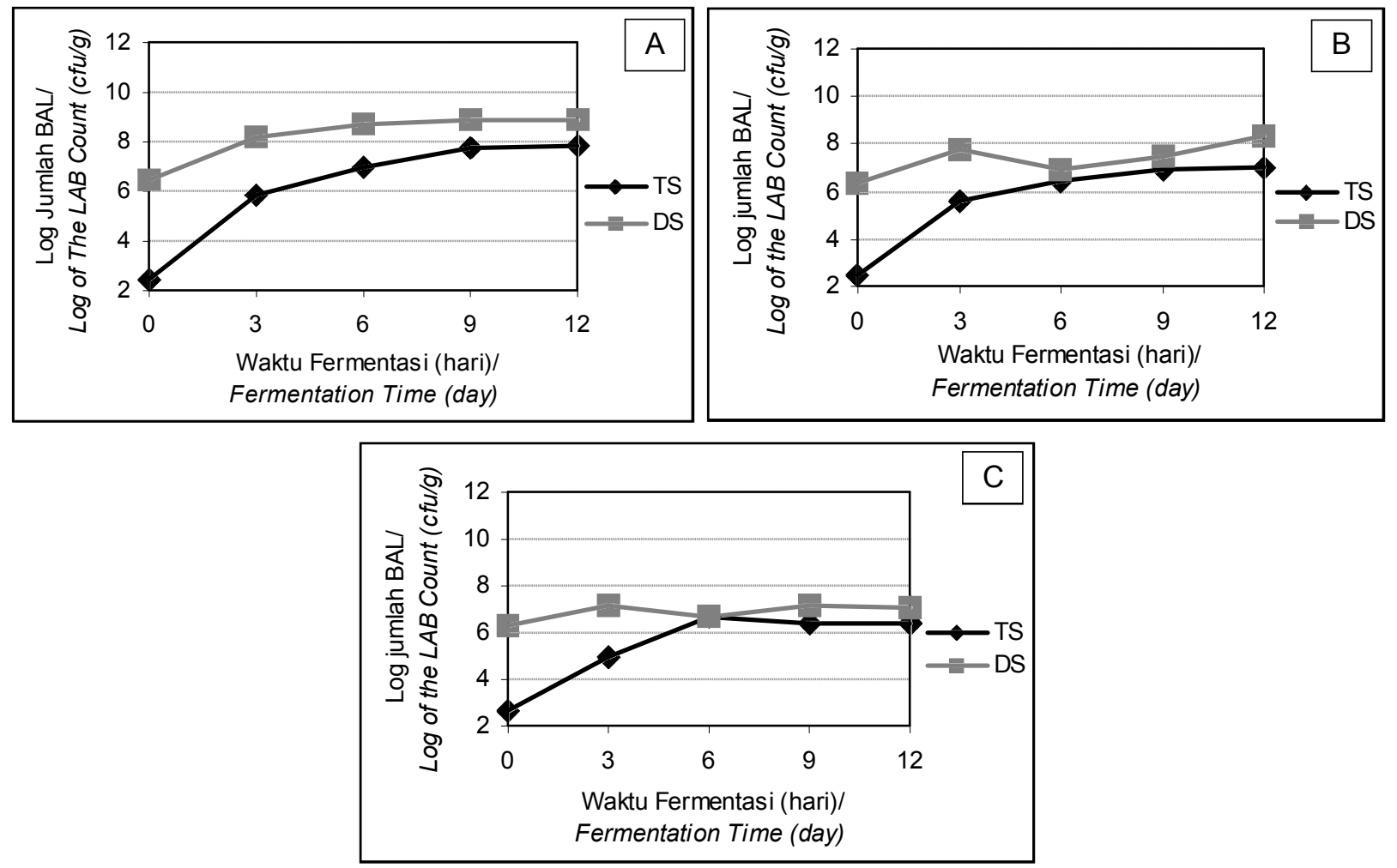

Gambar 3. Log jumlah BAL selama fermentasi pada A) kadar garam 10\%; B) kadar garam 15\%; dan C) kadar garam 20\% (TS: Tanpa Starter; DS: Dengan Starter).

Figure 3. Log of the $L A B$ count during fermentation on A) $10 \%$ salt; B) $15 \%$ salt and C) $20 \%$ salt (TS: without starter; DS: with starter). 
produk yang juga cenderung turun lebih cepat. Penurunan $\mathrm{pH}$ menyebabkan pertumbuhan bakteri menjadi terhambat, dan kebanyakan mikroorganisme tumbuh pada $\mathrm{pH}$ sekitar 5-8 dan hanya jenis tertentu mampu bertahan hidup pada pH rendah (Effendi, 2009).

\section{Bakteri Asam Laktat (BAL)}

Bakteri asam laktat merupakan bakteri yang berperan penting dalam proses fermentasi. Perubahan kandungan BAL pada rusip dengan dan tanpa starter P. acidilactici F-11 dapat dilihat pada Gambar 3. Dari Gambar tersebut dapat diketahui bahwa secara umum terjadi kenaikan jumlah BAL baik pada fermentasi dengan maupun tanpa starter hingga hari ke-12.

Pada fermentasi tanpa starter, jumlah BAL pada awal fermentasi adalah 2 log lebih rendah dari jumlah BAL dengan penambahan starter. Morzel et al. (1997) melaporkan bahwa populasi awal BAL rendah yaitu sekitar $5 \%$ dari total flora bakteri dalam ikan. Selama fermentasi 12 hari BAL meningkat, kecuali pada perlakuan penggaraman $20 \%$ yang menurun setelah hari ke-6. Kandungan BAL pada penggaraman $10 \%$ lebih tinggi dibandingkan dengan penggaraman 15 dan $20 \%$. Jumlah BAL dengan penggaraman $10 \%$ mencapai 8 log pada hari ke-12, sementara dengan

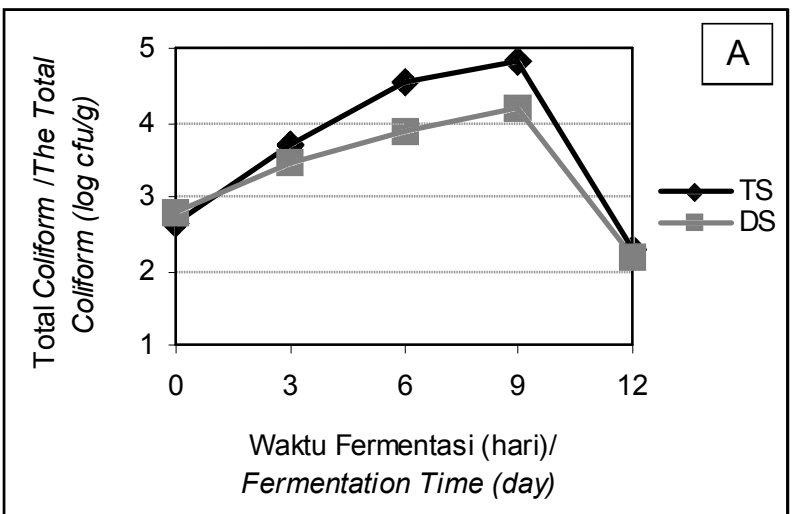

penggaraman 15 dan $20 \%$ berturut-turut mencapai 7 dan 6 log.

Pada fermentasi menggunakan starter jumlah BAL sudah sebesar 4 log cycle lebih tinggi dari jumlah bakteri awal pada ikan di awal proses pembuatan rusip (hari ke-0). Setelah difermentasikan selama 3 hari, jumlah BAL meningkat hingga puncaknya pada hari ke-6 sebesar 9 log (penggaraman 10\%), serta sebesar 8 dan 7 log masing-masing pada penggaraman 15 dan $20 \%$ (hari ke-3 dan ke-9). Hal ini menunjukkan bahwa penambahan starter mempercepat waktu fermentasi. Selain itu meningkatnya jumlah BAL berkorelasi dengan $\mathrm{pH}$. Jumlah BAL yang meningkat pada penggaraman 10 dan $15 \%$ terjadi seiring dengan menurunnya $\mathrm{pH}$, sedangkan jumlah BAL yang cenderung tidak meningkat pada penggaraman $20 \%$ (setelah hari ke3) terjadi seiring dengan $\mathrm{pH}$ yang konstan (Gambar 5C). Pertumbuhan BAL yang lebih datar pada penggaraman $20 \%$ ini terkait dengan kadar garam. Dengan kadar garam di atas $12 \%$ menyebabkan pertumbuhan BAL terhambat. Hal ini sejalan dengan Muller et al. (2002) yang menyebutkan bahwa pertumbuhan BAL secara optimal terjadi ketika kadar garam produk tidak lebih dari $6-7 \%$ dan pada kadar garam di atas $9 \%$ pertumbuhannya menjadi terhambat.

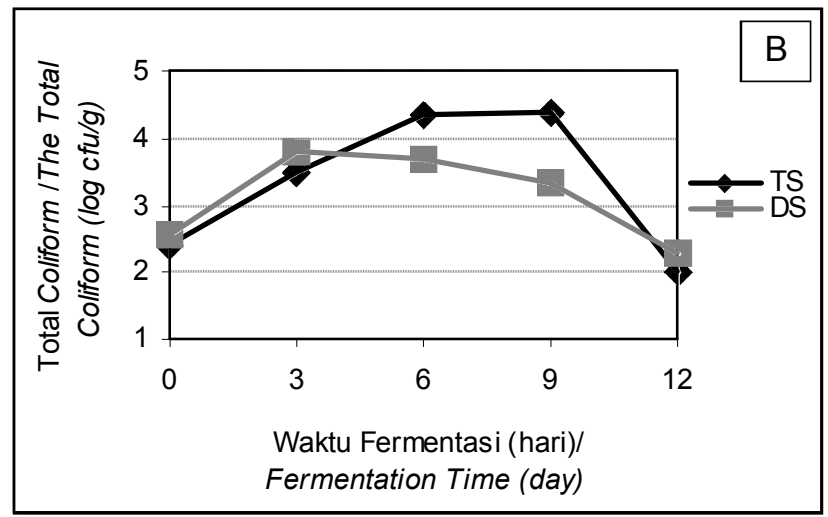

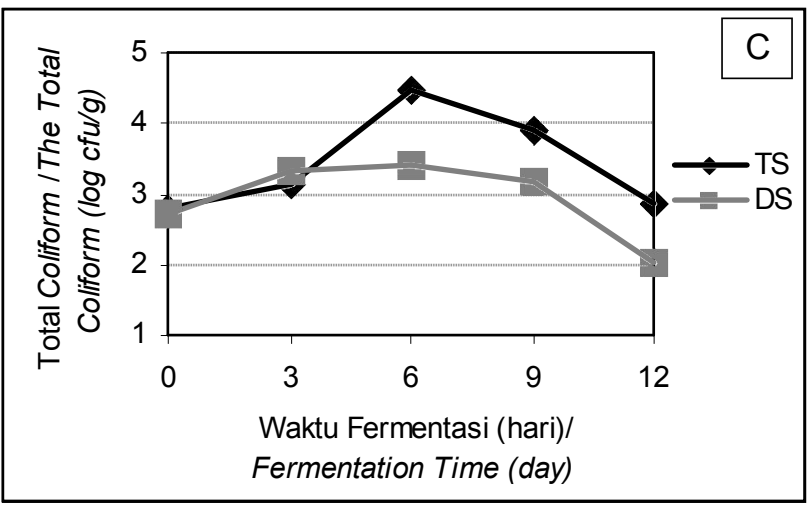

Gambar 4. Log total coliform selama fermentasi pada A) kadar garam 10\%; B) kadar garam 15\%; dan C) kadar garam 20\% (TS: Tanpa Starter; DS: Dengan Starter)

Figure 4. Log of the total coliform during fermentation on A) $10 \%$ salt; B) $15 \%$ salt and C) $20 \%$ salt (TS: without starter; DS: with starter) 
Semakin tinggi kadar garam yang terserap daging ikan, kandungan BAL semakin rendah. Hal ini disebabkan karena kemampuan BAL terhadap garam berbeda-beda. Dengan demikian dapat dikatakan bahwa pertumbuhan BAL tergantung pada konsentrasi garam.

\section{Total coliform}

Coliform merupakan bakteri indikator sanitasi dan higiene produk makanan. Adanya bakteri Coliform dalam produk pangan mengindikasikan bahwa produk tersebut telah terkontaminasi. Jumlah bakteri coliform pada rusip selama proses fermentasi dapat dilihat pada Gambar 4.

Mengacu pada Gambar 4 terlihat bahwa pada fermentasi tanpa starter terjadi peningkatan total coliform hingga hari ke-9 kecuali pada penggaraman $20 \%$, kemudian jumlahnya menurun. Sedangkan pada fermentasi dengan starter total bakteri coliform meningkat hingga hari ke-3, kecuali pada penggaraman $10 \%$ yang meningkat hingga hari ke-9.

Total coliform pada fermentasi tanpa starter ratarata lebih tinggi daripada fermentasi dengan menggunakan starter. Peningkatan total Coliform dimungkinkan karena kondisi $\mathrm{pH}$ media pada penggaraman $20 \%$ masih sesuai untuk coliform. Hasil analisis $\mathrm{pH}$ pada penggaraman $20 \%$ selama 12 hari fermentasi sekitar 6,05-6,21. Sementara E. coli tumbuh optimum pada pH 6,0-7,0 (Atlas, 2001 dalam Rinto, 2006). Total coliform pada penggaraman $10 \%$ mencapai 5 log cycle sedangkan pada penggaraman 15 dan $20 \%$ jumlah bakteri ini lebih rendah mencapai 4 log cycle (Gambar 4). Semakin tinggi garam yang ditambahkan mengakibatkan jumlah bakteri coliform semakin rendah. Penambahan starter menyebabkan penurunan total coliform dalam produk sebagaimana terlihat pada Gambar 4. Pada fermentasi 9 hari, total coliform pada perlakuan penambahan starter berkisar antara 3-4,1 log, sedangkan tanpa starter berkisar antara 4-4,8 log. Hal ini menunjukkan bahwa secara umum penambahan starter terbukti mampu menekan bakteri coliform. Setelah 9 hari fermentasi penggunaan starter untuk menekan bakteri coliform lebih nyata pada penggaraman $10 \%$ dibandingkan penggaraman 15 dan $20 \%$. Secara umum, penurunan total coliform pada produk rusip ini dimungkinkan karena tingginya kadar garam. Semakin tinggi kadar garam maka total coliform semakin rendah sebagaimana dilaporkan oleh Rinto (2006) bahwa penggunaan starter Pediococcus acidilactici F-11 pada awal fermentasi peda menyebabkan pengurangan kandungan bakteri coliform sebesar 2 log cycle pada penggaraman $20 \%$. Garam dapat menyeleksi mikrobia kontaminan,
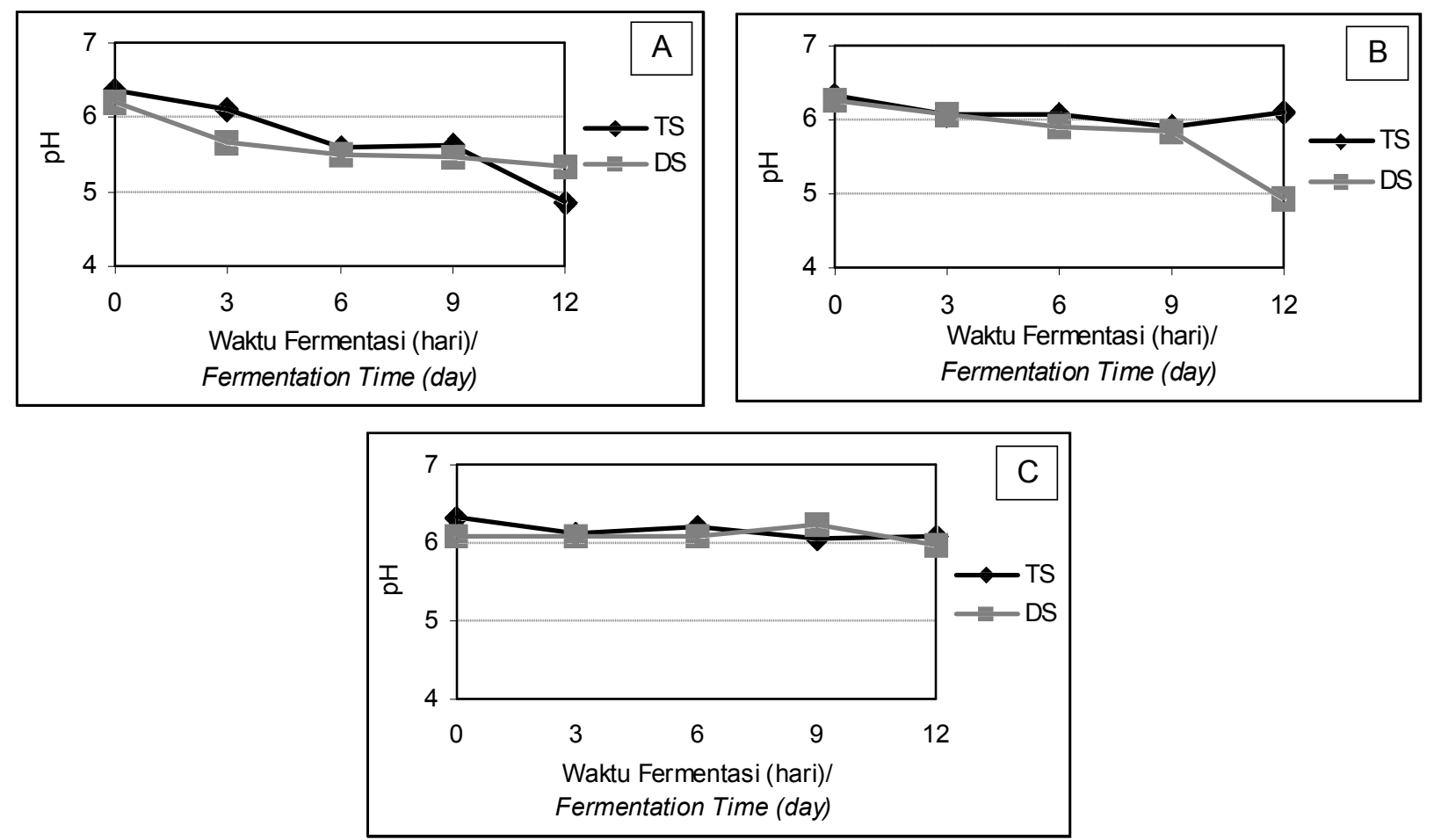

Gambar 5. pH rusip selama fermentasi pada A) kadar garam 10\%; B) kadar garam 15\%; dan C) kadar garam $20 \%$ (TS: Tanpa Starter; DS: Dengan Starter).

Figure 5. $\quad$ pH of rusip during fermentation on A) $10 \%$ salt; B) $15 \%$ salt and C) $20 \%$ salt (TS: without starter; DS: with starter). 
mengurangi nilai aktivitas air $\left(a_{w}\right)$ substrat, hilangnya air menyebabkan kejutan osmotik dan plasmolisis sehingga sel tidak mampu tumbuh (Ray, 1996). Kedua, bakteriosin (pediosin) yang dihasilkan $P$. acidilactici $\mathrm{F}-11$ dapat menghambat mikroorganisme yang tidak diinginkan termasuk coliform (Ray, 1996; Vennema, 1999 dalam Rinto, 2006).

\section{Perubahan Kimiawi Produk Rusip selama Fermentasi}

\section{$\mathrm{pH}$}

Selama proses fermentasi dengan maupun tanpa starter terjadi penurunan $\mathrm{pH}$ produk sejak awal hingga akhir fermentasi. Penurunan $\mathrm{pH}$ terjadi seiring dengan kenaikan jumlah bakteri asam laktat dan asam yang diproduksi. Dari Gambar 5 terlihat bahwa pada awal fermentasi pH ikan sekitar 6, kemudian pada fermentasi tanpa starter selama 12 hari dengan penggaraman $10 \%$ terjadi penurunan $\mathrm{pH}$ yang sangat tajam dari 6,37 menjadi 4,86 . Sedangkan pada penggaraman 15 dan $20 \%$, pH turun sedikit dari 6,33 menjadi 6,09 (15\%) dan dari 6,31 menjadi 6,08 (20\%).

Berbeda dengan fermentasi tanpa starter, fermentasi dengan penambahan starter menyebabkan penurunan $\mathrm{pH}$ yang sangat tajam pada penggaraman $10 \%$ dari 6,21 menjadi 5,34 . Pada penggaraman $15 \%$, $\mathrm{pH}$ turun secara tajam dari 6,27 menjadi 4,95.
Sedangkan pada penggaraman tinggi $20 \%$, $\mathrm{pH}$ turun sedikit dari 6,09 menjadi 5,98. Kondisi ini memperlihatkan bahwa penambahan starter dapat mempercepat terjadinya penurunan $\mathrm{pH}$. Namun penambahan starter pada penggaraman tinggi tidak efektif dalam mempercepat penurunan $\mathrm{pH}$ yang disebabkan bakteri asam laktat dalam produk tidak mampu tumbuh dan bekerja secara optimal. Kemudian selama fermentasi berlanjut penurunan $\mathrm{pH}$ masih terus berlangsung dan penurunan tersebut seiring dengan meningkatnya keasaman produk. Penurunan $\mathrm{pH}$ juga berkorelasi dengan penurunan jumlah bakteri aerob. Menurunnya jumlah bakteri aerob mengakibatkan menurunnya pelepasan ammonia yang diikuti dengan penggunaan asam amino oleh mikroorganisme perangsang fermentasi (Anihouvi et al., 2007).

Hasil analisis sidik ragam terhadap $\mathrm{pH}$ menunjukkan bahwa penambahan starter pada perlakuan penggaraman $10 \%$ (hari ke-3 dan 9) dan $15 \%$ (hari ke-12) berpengaruh nyata terhadap penurunan $\mathrm{pH}(\mathrm{p}<0,05)$. Hal ini terlihat jelas dari penurunan $\mathrm{pH}$ secara tajam pada perlakuan penggaraman 10 dan 15\% (Gambar 5A dan 5B).

\section{Total asam}

Pada fermentasi tanpa starter, total asam meningkat sejak awal hingga akhir fermentasi
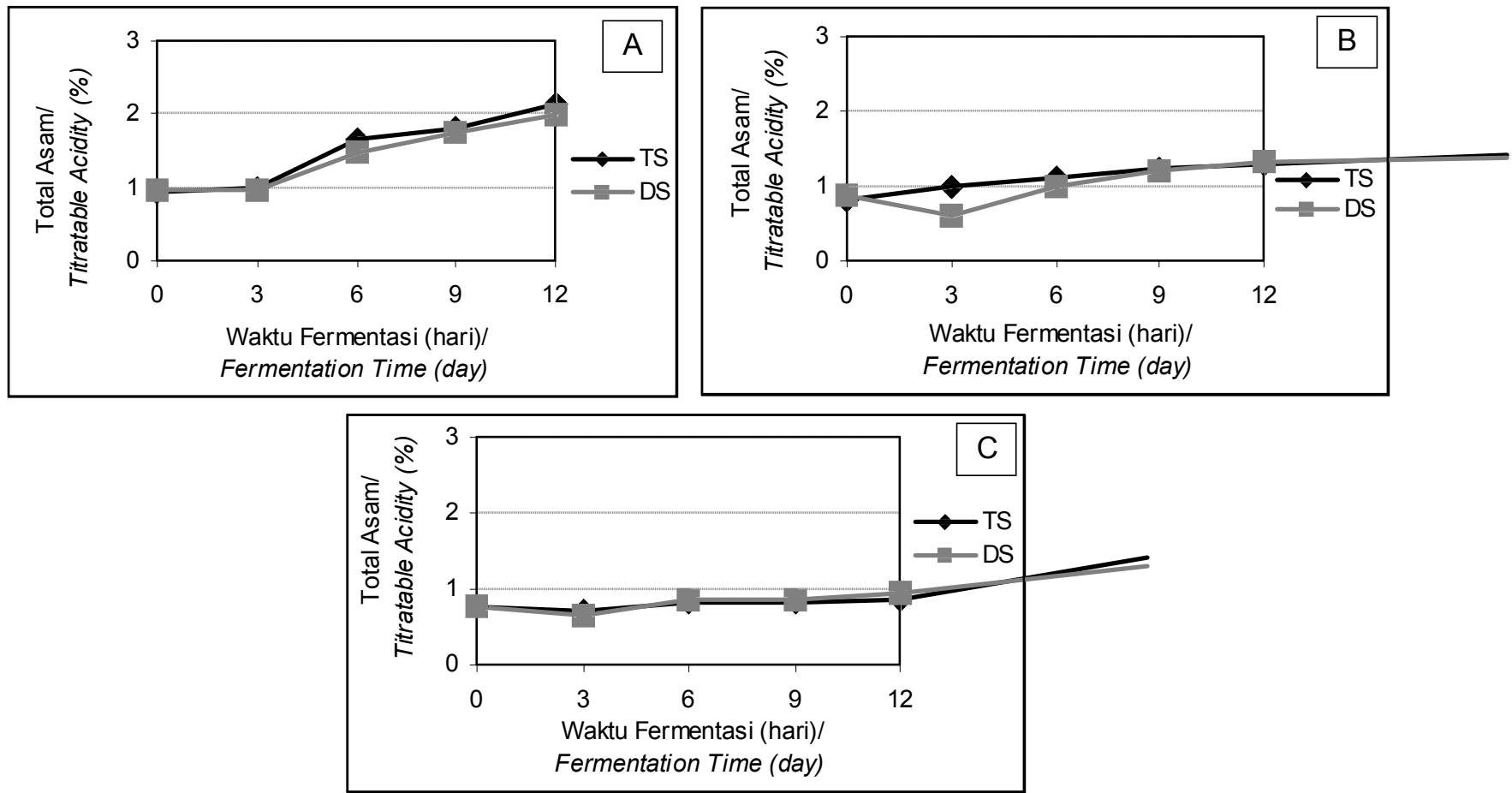

Gambar 6. Total asam rusip selama fermentasi pada A) kadar garam 10\%; B) kadar garam 15\%; dan C) kadar garam 20\% (TS: Tanpa Starter; DS: Dengan Starter).

Figure 6. Titratable acidity of rusip during fermentation on A) $10 \%$ salt; B) $15 \%$ salt and C) $20 \%$ salt (TS: without starter; DS: with starter). 
(Gambar 6). Begitu pula dengan rusip yang difermentasi dengan penambahan starter. Dalam hal ini, total asam pada fermentasi tanpa starter maupun dengan starter tidak jauh berbeda baik jumlah maupun polanya. Pada awal fermentasi tanpa starter, total asam berkisar antara 0,8-0,9\%, selanjutnya selama fermentasi 12 hari mengalami peningkatan. Total asam produk pada ketiga perlakuan penggaraman mencapai kadar tertinggi pada hari ke-12. Pada penggaraman $10 \%$, total asam mencapai kadar tertinggi sebesar $2,1 \%$ diikuti oleh penggaraman 15 dan $20 \%$ masingmasing sebesar 1,3 dan $0,9 \%$.

Pada fermentasi menggunakan starter, total asam tertinggi dicapai pada hari ke-12 pada ketiga perlakuan penggaraman. Pada penggaraman $10 \%$ terbentuk asam paling besar mencapai $2,0 \%$, diikuti oleh penggaraman 15 dan $20 \%$ masing-masing sebesar 1,7 dan $1,6 \%$. Tinggi rendahnya produksi asam ini berkorelasi dengan jumlah bakteri asam laktat. Pada Gambar 3, jumlah BAL paling tinggi, sebesar 9 log, di capai dengan penggaraman $10 \%$, paling rendah sebesar 7 log dengan penggaraman $20 \%$, dan sebesar 8 log dengan penggaraman 15\% (hari ke-12)

Jumlah BAL pada penggaraman $10 \%$ di hari ke12 paling tinggi sebesar 9 log (hari ke-12), sebesar 8 log dengan penggaraman 15\% (hari ke-12), namun dengan penggaraman $20 \%$ jumlah BAL di waktu yang sama paling rendah sebesar 7 log (Gambar 3). Semakin tinggi penggaraman maka jumlah BAL semakin rendah sehingga semakin rendah pula asam yang diproduksi. Sebagaimana dilaporkan oleh Muller et al. (2002) pada fermentasi plaa som (produk ikan fermentasi) pertumbuhan BAL secara optimal tergantung pada konsentrasi garam. Semakin tinggi kadar garam yang terserap daging ikan, maka semakin rendah kandungan BAL yang disebabkan kemampuan tumbuh BAL bervariasi menurut kadar garam. Berdasarkan Gambar 6, penambahan starter tidak berpengaruh nyata terhadap kenaikan total asam pada penggaraman 10, 15, dan 20\% (Gambar 6).

\section{TVB}

TVB merupakan indeks pembusukan pada produk ikan segar dan terfermentasi (Yongjin et al., 2007). Analisis TVB terkait dengan estimasi seluruh senyawa amina volatil yang diproduksi selama proses pembusukkan, termasuk amonia, dimetilamin, dan trimetilamin (Bonnel, 1994).

Berdasarkan Gambar 7, penurunan TVB pada fermentasi tanpa starter terjadi hingga akhir pengamatan, yaitu hari ke-12 pada ketiga konsentrasi penggaraman. Berbeda dengan fermentasi tanpa starter, pada fermentasi menggunakan starter terjadi penurunan nilai TVB secara tajam pada semua
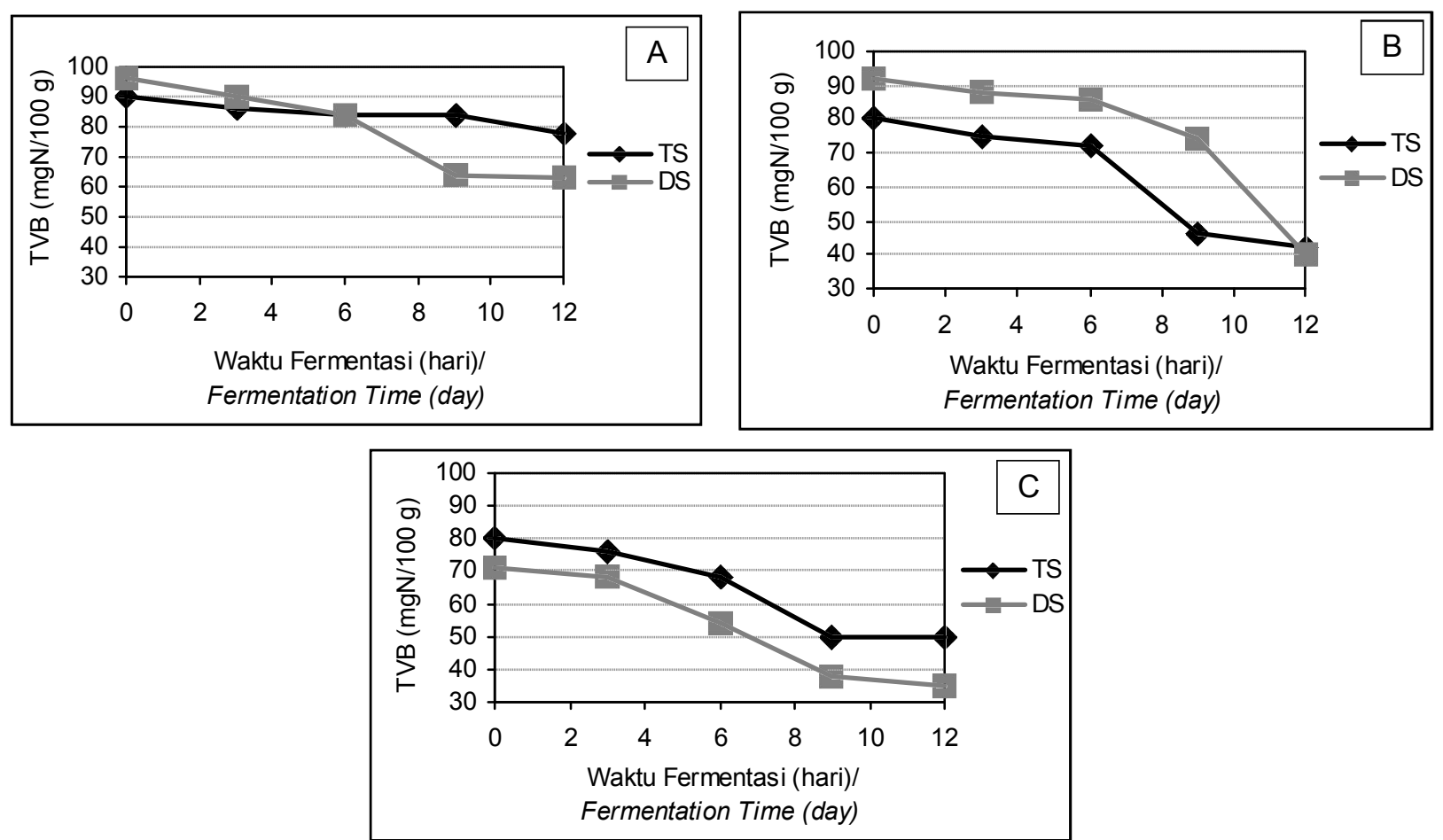

Gambar 7. TVB rusip selama fermentasi pada A) kadar garam 10\%; B) kadar garam 15\%; dan C) kadar garam 20\% (TS: Tanpa Starter;DS: Dengan Starter).

Figure 7. TVB of rusip during fermentation on A) $10 \%$ salt; B) $15 \%$ salt and C) $20 \%$ salt (TS: without starter;DS: with starter). 
konsentrasi penggaraman (Gambar 7A, 7B, dan 7C). Hingga hari ke-12 TVB menurun seiring kenaikan total asam (Gambar 6) dan pada saat itu jumlah BALnya juga mengalami peningkatan (Gambar 3). Total asam produk pada penggaraman $10 \%$ mencapai $2,0 \%$. Pada penggaraman $15 \%$ kadarnya lebih rendah sebesar $1,3 \%$, sedangkan pada penggaraman $20 \%$ total asam produk paling rendah sebesar $0,9 \%$. Jumlah BAL pada hari ke-12 sebesar 9 log (penggaraman 10\%), 8 log (penggaraman 15\%), dan $7 \log$ (penggaraman 20\%).

Nilai TVB rusip yang difermentasi tanpa starter secara umum lebih tinggi daripada yang difermentasi dengan starter. Pada penggaraman $10 \%$ melalui fermentasi tanpa starter nilai TVB paling tinggi mencapai $80 \mathrm{mgN} / 100 \mathrm{~g}$. Kemudian diikuti oleh penggaraman 15 dan $20 \%$ dengan pola penurunan lebih tajam masing-masing mencapai $42 \mathrm{mgN} / 100 \mathrm{~g}$ dan $50 \mathrm{mgN} / 100 \mathrm{~g}$. Penurunan nilai TVB yang lebih tajam pada perlakuan tersebut disebabkan karena pada konsentrasi garam yang lebih tinggi memungkinkan garam lebih mampu menyeleksi kehadiran bakteri pembusuk sehingga dapat menekan produksi basa-basa volatil. Dalam hal ini total coliform pada kadar garam 15 dan $20 \%$ adalah lebih rendah daripada total coliform pada kadar garam 10\% (Gambar 4).

Pada fermentasi menggunakan starter selama 12 hari, nilai TVB menurun sehingga nilainya menjadi lebih rendah daripada tanpa starter. Penurunan nilai TVB pada penggaraman $10 \%$ sebesar $15 \mathrm{mgN} / 100$ g. Pada penggaraman $15 \%$ nilai TVB berkurang 2 $\mathrm{mgN} / 100 \mathrm{~g}$ dari $42 \mathrm{mgN} / 100 \mathrm{~g}$ menjadi $40 \mathrm{mgN} / 100$ g. Sedangkan pada penggaraman $20 \%$ nilai TVB berkurang sebesar $15 \mathrm{mgN} / 100 \mathrm{~g}$ yaitu dari $50 \mathrm{mgN} /$ $100 \mathrm{~g}$ menjadi $35 \mathrm{mgN} / 100$. Kondisi ini memperlihatkan bahwa starter yang ditambahkan mampu menekan akumulasi TVB dalam produk. Hal ini sejalan dengan Yin et al. (2002) yang menyebutkan bahwa bakteri asam laktat mampu menghambat akumulasi TVB-N dengan memproduksi asam laktat dan bakteriosin, yang mampu menetralisir basa-basa nitrogen volatil kemudian menurunkan nilainya dalam produk.

\section{Kadar air dan kadar garam}

Perubahan kadar air rusip selama fermentasi tanpa starter maupun dengan penambahan starter dapat dilihat pada Gambar 8.
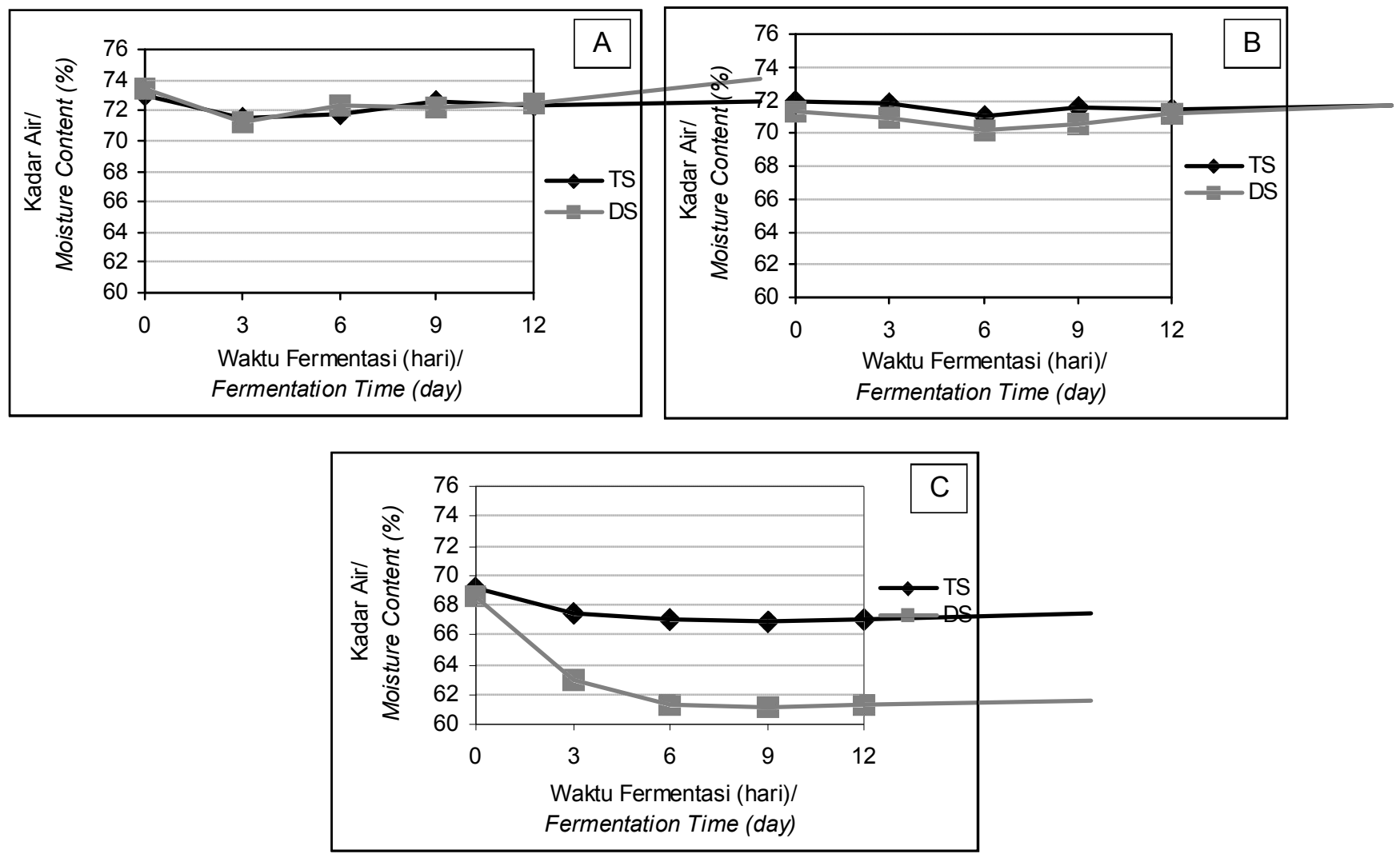

Gambar 8. Kadar air rusip selama fermentasi pada A) kadar garam 10\%; B) kadar garam 15\%; dan C) kadar garam 20\% (TS: Tanpa Starter; DS: Dengan Starter).

Figure 8. Moisture content of rusip during fermentation on A) $10 \%$ salt; B) $15 \%$ salt and C) $20 \%$ salt (TS: without starter; DS: with starter). 
Selama proses fermentasi 12 hari baik tanpa starter maupun dengan penambahan starter, kadar air ikan terfermentasi mengalami sedikit penurunan.

Penurunan kadar air dimungkinkan oleh proses hilangnya air melalui pori-pori penutup wadah yang tidak sepenuhnya tertutup rapat.

Berdasarkan Gambar $8 \mathrm{C}$ terdapat pola penurunan kadar air yang lebih tajam pada perlakuan garam $20 \%$. Pengurangan kadar air yang lebih besar ini terkait dengan tingginya kadar garam. Tingginya kadar garam yang diberikan di awal fermentasi menyebabkan semakin cepatnya molekul garam meresap ke dalam daging ikan. Pada saat bersamaan, cairan ikan tertarik ke luar sehingga menyebabkan kehilangan air lebih besar. Selain itu terdapat pula pola penurunan kadar air yang lebih tinggi pada rusip bergaram $20 \%$ dengan penambahan starter. Hal ini terkait dengan pertambahan jumlah bakteri akibat penambahan starter memungkinkan daging ikan lebih mudah diuraikan membentuk struktur yang kurang kompak. Kondisi ini mempercepat meresapnya garam sehingga mempermudah proses hilangnya air dari dalam daging.
Berdasarkan Gambar 9, kadar garam selama 12 hari pada fermentasi tanpa starter tidak mengalami perubahan, begitu pula dengan rusip dengan penambahan starter memperlihatkan pola serupa. Hal ini disebabkan karena selama proses fermentasi tidak ada penambahan garam.

\section{Mutu Sensori Produk Rusip}

Analisis sensori dilakukan dengan tujuan untuk mengetahui tingkat kesukaan panelis terhadap produk rusip serta mengetahui skor nilai sensori rusip berdasarkan atribut kenampakan, bau, rasa, dan tekstur. Tingkat penerimaan rusip dengan penambahan starter $P$. acidilactici F11 disajikan pada Tabel 4. Mutu hedonik rusip yang diinokulasi dengan penambahan starter adalah 4-5 (netral-agak suka), sedangkan skala penerimaan rusip tanpa starter lebih rendah yaitu 3-4 (agak tidak suka-netral). Sedangkan penilaian sensori produk rusip berdasarkan atribut kenampakan, bau, rasa, dan tekstur disajikan dalam Tabel 5.
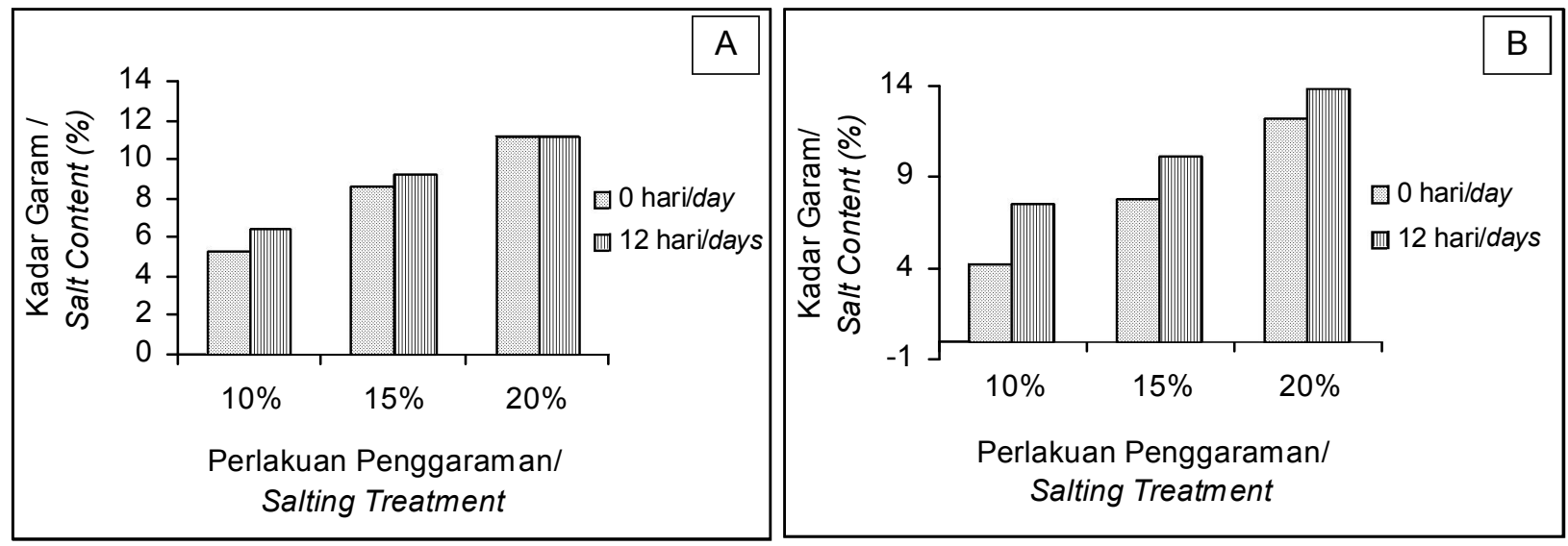

Gambar 9. Kadar garam rusip selama fermentasi A) Tanpa starter, B) Dengan starter (0 hari, 12 hari). Figure 9. Salt content of rusip during fermentation A) Without starter; B) With starter ( 0 day, 12 day).

Tabel 4. Mutu hedonik rusip

Table 4. Hedonic quality of rusip

\begin{tabular}{cc}
\hline Perlakuan/Treatment & Mutu Hedonik/Hedonic Quality \\
\hline Tanpa starter/Without starter: & \\
$10 \%$ & 4.33 \\
$15 \%$ & 3.78 \\
$20 \%$ & 4.11 \\
Dengan starter/With starter: & \\
$10 \%$ & 4.33 \\
$15 \%$ & 4.56 \\
$20 \%$ & 4.00 \\
\hline
\end{tabular}


Tabel 5. Mutu sensoris rusip dengan variasi penambahan garam

Table 5. Sensory quality of rusip with variation of salt addition

\begin{tabular}{ccccc}
\hline Perlakuan/Treatment & $\begin{array}{c}\text { Kenampakan/ } \\
\text { Appearance }\end{array}$ & Bau/Odour & Rasa/Taste & Tekstur/Texture \\
\hline Tanpa starter/Without starter: & & & & \\
$10 \%$ & 2.44 & 3.33 & 3.22 & 4.22 \\
$15 \%$ & 3.00 & 3.44 & 3.33 & 3.33 \\
$20 \%$ & 3.00 & 3.89 & 3.22 & 3.20 \\
10\% & & & & \\
$15 \%$ & 3.11 & 3.56 & 3.44 & 3.44 \\
$20 \%$ & 2.78 & 3.33 & 3.67 & 3.67 \\
Dengan starter/With starter: & 3.44 & 3.56 & 3.30 & 3.33 \\
\hline
\end{tabular}

Berdasarkan Tabel 5, secara umum skor kenampakan produk rusip tanpa starter lebih rendah daripada rusip dengan penambahan starter yang memberikan kenampakan ikan lebih utuh, warna coklat keabu-abuan dan lebih cerah. Hal ini terkait dengan asam laktat dan pediosin yang dihasilkan $P$. acidilactici F-11. Kedua metabolit tersebut menghambat aktivitas proteolitik dari mikroorganisme yang tidak diinginkan termasuk bakteri pembusuk maupun patogen yang berasosiasi dengan produk (Ray, 1996; Vennema, 1999 dalam Rinto, 2006).

Bakteri dengan aktivitas proteolitik merombak protein daging ikan menjadi asam-asam amino yang selanjutnya bereaksi dengan glukosa (reaksi Maillard) yang menimbulkan warna kecoklatan pada daging ikan (Vennema, 1996). Terhambatnya pertumbuhan bakteri pembusuk menyebabkan kenampakan fisik daging ikan dapat dipertahankan sehingga menghasilkan daging ikan lebih utuh dan lebih cerah.

Berdasarkan hasil analisis rasa, rusip dengan penambahan starter lebih baik daripada rusip tanpa starter. Rusip dengan penambahan starter tidak gatal, rasa gurih dan asin seimbang, sedikit asam serta segar spesifik produk berkurang, sedangkan rusip tanpa starter tidak gatal, kurang gurih, terasa asin dan asam. Dalam hal ini asam laktat yang dihasilkan dari bakteri asam laktat berperan penting memunculkan karakter asam dan meningkatkan rasa asin yang mungkin menutupi flavor yang lain (Riebroy et al., 2008).

Selain asam laktat juga terdapat asam amino yang berkontribusi besar terhadap rasa produk fermentasi ikan. Sebagaimana dilaporkan oleh ljong \& Ohta (1995) bahwa asam aspartat, asam glutamat, serin, arginin, treonin, alanin, prolin, valin, isoleusin, dan fenilalanin merupakan asam-asam amino yang berkontribusi terhadap flavor bakasang (produk fermentasi ikan).
Perlakuan garam $15 \%$ dengan penambahan starter memperlihatkan skor penerimaan rasa lebih tinggi daripada perlakuan garam 10 dan $20 \%$. Dibandingkan dengan rusip tanpa starter dengan perlakuan garam yang sama $(15 \%)$ juga memperlihatkan skor penerimaan rasa lebih baik. Rasa rusip baik tanpa maupun dengan starter dinilai rendah oleh panelis terkait dengan rasa asam yang mendominasi produk. Sementara produk komersial yang dijadikan sebagai acuan penentuan skor sheet produk rusip memiliki rasa gurih, asin dan asam seimbang. Hal ini disebabkan garam yang ditambahkan di awal proses pengolahan rusip komersial jauh lebih tinggi (mencapai $25 \%$ ). Pada konsentrasi garam yang lebih tinggi, memungkinkan pertumbuhan bakteri asam laktat yang secara alami berperan dalam proses menjadi kurang optimal sehingga kemampuannya mengasamkan produk menjadi lebih rendah. Hal ini tercermin dari nilai $\mathrm{pH}$ produk rusip komersial yang lebih tinggi $(5,35-6,27)$ (Heruwati et al., 2010). Sementara produk rusip yang diberi perlakuan garam lebih rendah dan diberi starter (10 dan 15\%), memiliki $\mathrm{pH}$ berkisar 4,95 hingga 5,34 pada hari ke-12 fermentasi. Oleh karenanya untuk mendapatkan produk rusip dengan derajat keasaman yang diinginkan/lebih dapat diterima panelis, seharusnya fermentasi dihentikan sebelum hari ke-12.

Secara umum, rusip yang diinokulasi dengan starter memperlihatkan tingkat penerimaan tekstur lebih tinggi daripada rusip tanpa starter. Rusip dengan penambahan starter pada perlakuan garam 15\% memperlihatkan skor penerimaan tekstur lebih tinggi daripada perlakuan garam 10 dan $20 \%$. Penambahan starter menyebabkan tekstur rusip menjadi lebih kompak, padat dan sedikit masir, sedikit lebih baik kondisinya dibandingkan rusip tanpa starter yang bertekstur kurang kompak, sedikit lembek, dan masir. Diduga tekstur rusip yang lebih kompak dan padat berkaitan dengan asam laktat dan pediosin yang dihasilkan $P$. acidilactici F-11. Kedua metabolit 
tersebut menghambat aktivitas proteolitik dari bakteri pembusuk maupun patogen yang berasosiasi dengan produk (Vennema, 1999 dalam Rinto, 2006). Anihouvi et al. (2007) mengemukakan bahwa bakteri pembusuk/patogen seperti Bacillus spp. dan Staphylococcus spp. yang diisolasi dari lanhouin (produk fermentasi ikan) memiliki aktivitas proteolitik dan esterolitik yang menyebabkan perubahan tekstur pada produk.

\section{KESIMPULAN}

Penambahan Pediococcus acidilactici F-11 sebagai kultur starter untuk memperbaiki kualitas rusip memberikan nilai sensori terbaik, terutama rasa dan tekstur pada penggaraman $15 \%$ dengan waktu fermentasi 9 hari. Rusip yang dihasilkan mempunyai kandungan ALT produk sebesar 9,63 log; total BAL sebesar 7,47 log; total coliform 1 log lebih rendah daripada rusip tanpa starter yaitu dengan nilai 3,34 log; $\mathrm{pH}$ 5,83; total asam 1,2\%; dan TVB 74 mgN/100 g.

\section{DAFTAR PUSTAKA}

Anihouvi, V.B., Dawson, E.S., Ayernor, G.S., and Hounhouiga, J.D. 2007. Microbiological changes in naturally fermented cassava fish (Pseudolithus sp.) for lanhoin production. International J. of Food Microbiology. 116: 287-291.

Anonymous. 2007. Probiotic. http://en.wikipedia.org/wiki/ probiotic. Diakses pada tanggal 9 Oktober 2008. 12 pp.

AOAC. 1999. Official Methods of Analysis of AOAC International, vol. 2, $16^{\text {th }}$ ed. Association Official of Analytical Chemist. Washington DC. 1018 pp.

Bonnel, A.D. 1994. Quality Assurance in Seafood Processing: A Practical Guide. Chanpman and Hall, Inc., New York.

Cocconcelli, P.S. 2007. Starter cultures: bacteria. In Toldra, F. (ed.). Handbook of Fermented Meat and Poultry. Blackwell Publishing, UK. 545 pp.

Connel, J.J. 1980. Control of Fish Quality: Quality Deterioration and Defects in Products. England. Fishing New Books Ltd. p. 56-105.

Effendi, M.S. 2009. Teknologi Pengolahan dan Pengawetan Pangan. Penerbit Alfabeta, Bandung. $202 \mathrm{pp}$.

Endang, S.H., Murtini, J.T., Indriati, N., Ariyani, F., Dwiyitno., Andayani, F., Priyanto, N., Siregar, T.H., Rachmawati, N., dan Triwibowo, R. 2010. Penelitian Teknologi Pengolahan, Pengemasan dan Penyimpanan Tropical Cat fish, Nila dan Bandeng yang Aman dari Pembentukan Residu Bahan Berbahaya. Laporan Teknis. Balai Besar Riset Pengolahan Produk dan Bioteknologi Kelautan dan Perikanan.

Galvez, A., Abriouel, H., Lopez, L., and Omar, N.B. 2007. Bacteriocin-based strategies for food biopreservation. International J. of Food Microbiology. 120: 51-70.
Gram, L., Ravn, L., Rasch, M., Bruhn, A. B., Christensen, A.B., and Givskov, A.B. 2002. Food spoilageinteraction between food spoilage bacteria. J. of Food Microbiology. 78: 79-97.

Hutkins, R.W. 2006. Microbiology and Technology of Fermented Food. Blackwell Publishing Ltd, UK. 475 $\mathrm{pp}$.

ljong, F.G. and Ohta, Y. 1995. Microflora and chemical assessment of an traditional fermented fish sauce "Bekasang". J. Fac. Appl. Biol. Sci. 34: 95-100.

Ilminingtyas, D., Hadiwiyoto, S., Wisesa, D., dan Naruki, S. 2000. Pembentukan fraksi-fraksi protein selama fermentasi peda. Agrosains. 13(1): 1-17.

Kusmiati dan Malik, A. 2002. Aktivitas bakteriosin dari bakteri Leuconostoc mesenteroides Pbac1 pada berbagai media. Makara Kesehatan. 6(1): 1-6.

Madani, A., Koesoemawardani, D., dan Susilawati. 2007. Karakteristik rusip dari Pulau Bangka.http:// www.unila.ac.id/ fp/index.php?option=com_content\& task=view \&id=103\&itemid=256. Diakses pada tanggal 23 Agustus 2009.

Muller, C.P., Madsen, M., Sophanodora, P., Gram, L., and Moller, P. L. 2002. Fermentation and microflora of plaasom, a Thai fermented fish product prepared with different salt concentration. J. Food. Microbiology. 73: 61-70.

Morzel, M., Fransen, and Arendt, E.K. 1997. Define starter cultures used for fermentation of salmon fillets. $J$. Food Sci. 62(6): 1214-1218.

Nendissa, S.J. 2001. Pemanfaatan Kultur Pediococcus acidilactici F11 Penghasil Bakteriosin untuk Memperbaiki Kualitas "Ina sua" (Ikan Asin) Gurame (Osphronemus gouramy Lacepede). Tesis. Sekolah Pascasarjana. Universitas Gadjah Mada, Yogyakarta. $88 \mathrm{pp}$.

Nurulita, E., Susilawati, dan Yuliana. 2007. Pengaruh penambahan kultur cair bakteri asam laktat pada rusip.http://www. unila.ac.id/ fp/index.php? option $=$ com_content\&task=view\&id=103\& itemid=256. Diakses pada tanggal 23 Agustus 2009.

Ray, B. 1996. Fundamental Food Microbiology. CRC Press. London. 516 pp.

Sakti, T.P.J. 2009. Analisis Sifat-Sifat Probiotik Bakteri Asam Laktat Asal Rusip. Skripsi. Fakultas Pertanian Universitas Sriwijaya. $35 \mathrm{pp}$.

Steel, R.G.D. and Torie, J.H. 1989. Prinsip dan Prosedur Statistika, $2^{\text {nd }}$ ed. PT Gramedia, Jakarta. 748 pp.

Rahayu, 1997. Lactic acid bacteria in fermented foods of indonesian origin. Agritech. 23(2): 75-84.

Riebroy, S., Benjakul, S., and Visessanguan, W. 2008. Properties and acceptability of som-fug, a Thai fermented fish minced, inoculated with lactic acid bacteria starters. LWT. 41: 569-580.

Rinto. 2006. Pediococcus acidilactici F11 sebagai Biokontrol Pembentukan Histamin pada Fermentasi Peda. Tesis. Sekolah Pascasarjana. Universitas Gadjah Mada, Yogyakarta.102 pp.

Badan Standarisasi Nasional (BSN). 2006. SNI 012332.3-2006. Cara uji mikrobiologi. Bagian 3. 
Penentuan Angka Lempeng Total (ALT) pada produk perikanan. Badan Standarisasi Nasional. 11 pp.

Badan Standarisasi Nasional (BSN). 2009. SNI 7388. 2009. Batas Maksimum Cemaran Mikroba dalam Pangan. Badan Standarisasi Nasional, Jakarta. 37 pp.

Tanasupawat, S. dan Komagata, K. 1999. Lactic acid bacteria in fermented foods in Southeast Asia. In Nga, B.H., Tan, H.M. and Suzuki, I. (eds.). Microbial Diversity in Asia Technology and Prospects. World Scientific. Singapura. $252 \mathrm{pp}$.

Ustadi, Suparmo, dan Rahayu, E.S. 2004. Penyiapan starter kering bakteri asam laktat halofilik untuk pengolahan hasil perikanan fermentatif bergaram. Agritech. 24(2): 41-47.

Van Veen, A.G. 1965. Fermented and dried seafood product in Southeast Asia. In Borgstrom, G. (ed.). Fish as Food. Academic Press Inc London Ltd. 489 pp.
Vennema, O.R. 1996. Food Chemistry. Marcel Dekker Basel.

Wood and Holzapfel. 1995. The Genera of Lactic Acid Bacteria Vol 2. Blackie Academic \& Professional. London. 398 pp.

Yang, R. and Ray, B. 1992. Factor influencing production of bacteriocin by lactic acid bacteria. Food Microbiology. 11: 281-292

Yin, L., Pan, C., and Jiang, S. 2002. Effect of lactic acid bacterial fermentation on the characteristics of minced mackerel. Journal of Food Science. 67(2): 786-792.

Yongjin, Hu., Wenshui, X., and Xiaoyong. 2007. Changes in biogenic amine in fermented silver carp sausages inoculated with mixed starter cultures. Food Chemistry. 104: 188-195.

Yuliana, N. 2007. Profil fermentasi rusip yang dibuat dari ikan teri (Stolephorus sp.). Agritech. 27(1): 12-17. 